\title{
"Bridging Activities," New Media Literacies, and Advanced Foreign Language Proficiency
}

\author{
SteVen L. Thorne \\ The Pennsylvania State University \\ JonATHON REINHARDT \\ University of Arizona
}

\begin{abstract}
In this article we propose the pedagogical model bridging activities to address advanced foreign language proficiency in the context of existing and emerging internet communication and information tools and communities. The article begins by establishing the need for language and genre-focused activities at the advanced level that attend to the shifting social practices and emerging literacies associated with digital media. Grounded in principles of language awareness and the concept of multiliteracies, the bridging activities model centers on guided exploration and analysis of student selected or created digital vernacular texts originating in Web 2.0 and other technologies/practices such as instant messaging and synchronous chat, blogs and wikis, remixing, and multiplayer online gaming. Application of the model includes an iterative implementation cycle of observation and collection, guided exploration and analysis, and creation and participation. In sum, the bridging activities approach is designed to enhance engagement and relevance through the incorporation of students' digital-vernacular expertise, experience, and curiosity, coupled with instructor guidance at the level of semiotic form to explore interactional features, discourse-level grammar, and genre. The ultimate goal is to foster critical awareness of the anatomy and functional organization of a wide range of communicative practices relating to both digital and analogue textual conventions.
\end{abstract}

\section{KEYWORDS}

Bridging Activities, Web 2.0, Internet-mediated Communication, Mutiplayer Online Games

\section{THE CHALLENGES OF ADVANCED LANGUAGE PROFICIENCY}

In its 25 year history, the CALICO Journal and monograph series publications have provided venues for a wide variety of applied linguistics research in the area of second and foreign language learning aided by machine local software applications and an array of internetenabled information, communication, and computational tools. As a selective but salient representative of this work, the seven recent articles to have won the "Outstanding CALICO Journal Article Award" include the themes of intelligent tutoring in the context of Japanese L2 reading (Kang \& Maciejewski, 2000), a Vygotskian analysis of interactional features of Spanish language synchronous chat (Darhower, 2002), a psycholinguistic assessment of Spanish language synchronous chat focusing on the role of working memory (Payne \& Whitney, 2002), the use of communication strategies in an asynchronous German-English intercultural exchange (Savignon \& Roithmeier, 2004), a wide-ranging article describing emerging internet communication tools and contexts and intelligent computer-assisted language learning applications (Thorne \& Payne, 2005), the discussion of a prototype tool (iWRITE) designed to provide intermediate learners of English with explicit composition related grammatical and 
lexical assistance (Hegelheimer \& Fisher, 2006), and, most recently, the application of second language acquisition and cognitive psychology research to inform design features relevant to computer-based lexical acquisition environments and activities (Lafford, Lafford, \& Sykes, 2007). The breadth of topics, technologies, and languages represented in this sample of articles illustrate the vibrancy, as well as the diversity, of technology-assisted language education research and pedagogy.

The intent of this article is to contribute to an area that has received relatively little attention within technology-mediated language education research, namely, the conditions and opportunities associated with advanced foreign language proficiency in the context of existing and emerging internet communication and information tools and communities. In the face of a vast array of non-English culture and language media, increases in diaspora populations around the world, and the increasing penetration of world events into the lives of Americans (with its implications for national security), one would surmise that university level coursework focused on developing advanced foreign language expertise, technology related or otherwise, would not be the exception that it is in the United States. Lambert (2001), for example, describing the low percentage of US students who study a foreign language at the advanced level, estimates that only $3 \%$ of those studying commonly taught languages such as Spanish or French enroll in advanced level courses. Though support for less commonly taught languages such as Arabic has recently increased (student enrollments doubling between 1998 and 2002, see Modern Language Association, 2007), enrollments at advanced levels in less commonly taught languages are presumably even fewer in number.

An additional problem is that upper level foreign language courses tend to emphasize literature, a worthwhile pursuit to be sure, but one that is specific in its linguistic, stylistic, and pragmatic content and arguably of limited generalizability in application to professional and interpersonal contexts of communication. Related to the dominant concentration on literature at advanced levels of foreign language coursework, there are relatively few languagefocused pedagogical texts or materials that focus on mastery of subtle features of interactive spoken and written discourse (though see discussion below; see also Strauss, Lee, \& Ahn, 2006; Strauss, 2006). The relative paucity of language focused advanced level pedagogical materials is understandable given the current fiscal climate that increasingly makes the academy accountable to private sector logic; the small number of students in advanced language courses make the labor intensive construction of advanced level language materials a nonutilitarian choice. Additionally, the tendency for a sharp distinction between language- and literature-oriented foreign language courses, with low prestige associated with the former and high status with the latter, has engendered an enduring symbolic capital divide separating intellectual labor associated with each of these instructional practices, this despite the sophisticated movement associated with stylistics (Carter \& Simpson, 1989; Widdowson, 1992) and linguistic criticism (Fowler, 1986).

As further evidence of the need for attention to specifically technology-mediated arenas of language use in relation to advanced foreign language proficiency, in the past 5 years, there has been a renaissance of interest in, and attention to, issues of advancedness. Two edited volumes have been published that focus on advanced foreign language acquisition, pedagogy, and programmatic/curricular planning (Byrnes \& Hiram, 2004; Leaver \& Shekhtman, 2002). Yet more recently, two additional edited books have emerged which examine advanced foreign language proficiency from a wide array of theoretical and methodological positions, including genre, systemic functional, Vygotskian sociocultural approaches (Byrnes, 2006), and cognitive and conceptual grammar perspectives (Byrnes, Weger-Guntharp, \& Sprang, 2007; for a review, see Thorne, in press). Of the 47 chapters comprising these four volumes, only one directly addresses technology issues, and it covers only one project, the LangNet initiative, which involves a set of narrowly focused online materials designed to bring 
foreign language learners' reading ability up to superior-distinguished levels (see Ingold, 2002). Byrnes (2007) has noted that despite the obvious need for advanced foreign language capacities and the clear limitations of current instructional practices, the advanced learner is often overlooked in second language acquisition theory and research and continues to receive insufficient pedagogical attention. As is obvious from the discussion above, another gap in advanced foreign language pedagogy and research is in the arena of technology-mediated communication, which arguably is now a high-frequency context for language use at any proficiency level.

\section{CONTEXT: INTERNET MEDIATION AND CONTEMPORARY CONTEXTS OF COMMUNI- CATION}

In everyday interaction, from professional workplaces and educational contexts to social and interpersonal communication, internet information and communication technologies have transformed conventional communicative practices in the areas of audience, impact, and speed and have enabled the emergence of new forms of communicative, cultural, expressive, and social activity. Emerging information and communication media now mediate globally disseminated processes of language development and literate engagement (Lankshear \& Knobel, 2006; Thorne, 2008a).

For teens and university age students, emerging literacies associated with digital media are highly relevant to their current and future lives as language users. Especially for younger individuals growing up with (and through) the use of internet information and communication tools, it is apparent that social as well as academic communication is mediated by participation in Web 2.0 and other digital environments such as social networking sites (e.g., http:// www.facebook.com, http://www.myspace.com, http://twitter.com), blog networks, websites, instant messaging, gaming, and voice and text messaging over cell phones (see Thorne \& Black, 2008; Thorne, 2008b). The massive increase in participation in mediated communication environments suggests that for many individuals, performing linguistically structured identities in second and foreign languages now involves digital mediation as often as, or more often than, nondigital forms of communication. Hence, for many late modern communicators, advanced language proficiency will include the use of many more communicative modalitiesand their attendant contexts and appropriate genres of communication-than would have been the case even a decade ago.

It is also clear that the internet used to be, and in many educational contexts continues to be, a place simply to practice the L2. However, demographic data strongly suggest that the internet is now one of the most important arenas for all manner of communicative activity (see Castells, 2004), a fact which suggests that foreign language educators should be targeting awareness of internet-specific genres as an explicit goal of formal instruction. In essence, the aesthetic and stylistic shifts in communicative contexts, purposes, and genres of language use associated with new media necessitate a responsive and proactive vision of foreign and second language instruction.

\section{A REPORT FROM THE FIELD: TECHNOLOGY AND ADVANCED LANGUAGE LEARNING}

The Center for Advanced Language Proficiency Education and Research (CALPER) is one of 15 title-VI-funded national foreign language resource centers. While all CALPER projects address advanced foreign language learning, the remainder of this article will provide a brief overview of the CALPER Technology Project, which focuses on advanced foreign language learning through the use of internet information and communication tools. Our efforts are currently 
oriented toward critically examining and leveraging technology-mediated everyday communicative functioning in the areas of emerging literacies, information gathering and sharing, knowledge building, problem solving, and social and professional activity and to use these authentic contexts as resources for promoting language awareness and language learning. In particular, the Project focuses on pedagogical innovation within two computer-mediated configurations: (a) instructed and institutional intraclass activity (described briefly in the appendix to this article) and (b) interaction in ongoing internet-mediated environments that include blogs, wikis, websites, fanfiction communities, and online virtual environments and games. It is this second category of new media literacies that we explore in the remainder of this article.

\section{ADVANCED LANGUAGE USE IN DIGITAL COMMUNICATION}

The CALPER Technology Project seeks to identify broad genres of everyday digital communication, to provide guidance in utilizing internet communication tools in instructed foreign language contexts, and to describe approaches for heightening foreign language instructors' and students' awareness of new media literacies. The Project also emphasizes the importance of interpersonal relationship and community building within computer-mediated interaction as potential catalysts for the development of advanced foreign language proficiency, either as a design element of foreign language instruction or as a more organic function of participation in online interaction.

While many forms of communication are flexible and variable across contexts and communities, most genres of formal writing tend to have long histories and well established, explicit, and constraining conventions dictating appropriate usage. Of course, the digital age incorporates virtually all genre conventions associated with traditional forms of written language that range from expository and technical texts to works of creative fiction. However internet mediation has also spawned a wide array of new epistolary conventions. What is sometimes called the multiliteracies approach (Cope \& Kalantzis, 2000; New London Group, 1996; see also Kress, 2003; Roth, 2006) has been richly instrumental in exploring and assessing globally distributed internet-mediated activity involving multiple languages and other forms of semiotic mediation. Many of these new literacy practices-such as multimodal compositions, combined uses of voice and text, both localized and globally distributed conventions for text messaging, email, synchronous chat, and instant messaging, and communication via avatar in online gaming environments-extend beyond traditional print-based text. In essence, the use of the internet, both in and out of educational settings, often involves participation in communicative genres that diverge from analogue-normative textual conventions (e.g., see Black \& Steinkuehler, in press; Crystal, 2001; Herring, 1996; Thorne \& Black, 2007, 2008).

\section{A PEDAgogical PROPOSAL: "BRIDgINg ACTIVItIES," NEW MEdiA literACIES, AND ADVANCED FOREIGN LANGUAGE PROFICIENCY}

To address the important area of everyday uses of the internet, in other words new media vernaculars that are coming to influence recreational, social, and increasingly professional contexts of communication, the Project has published working papers reviewing various research on new media literacies (Thorne \& Black, 2007) and is working to develop a languageawareness-based pedagogical framework complete with supporting materials. In comparison to their conventional genre counterparts, new media literacies as they exist in naturally occurring contexts are somewhat elusive and challenging to definitively identify and teach. Additionally, community-specific genres of communication are perennially expanding across global networks as new tools, communities, and purposes emerge. The question arises, how might 
one select, and then teach, genres of mediated language use that are themselves rapidly transforming, or which may be transient or soon to pass out of vogue, within instructed foreign language settings? For example, what do we make of the talk-in-interaction occurring within hugely popular massively multiplayer online gaming environments (e.g., Thorne, 2008c)? Or what about many other high-frequency online communities and tools that increasingly occupy our communicative and informational lives such as blogging, collaborative writing in wikis or googledocument environments (e.g., Sykes, Oskoz, \& Thorne, 2008), computer-based instant messaging and text messaging on cell phones, robust online communities supporting in-country and diaspora populations (e.g., Cyworld, see Lee, 2006), and fanfiction sites (e.g., Black, 2006, 2007)? The list is very long. Just beyond the tech-sex appeal and monitor halos, however, rest the same issues and questions that have confronted teachers and researchers for decades (and millennia): What will (or should) students learn? How are the task and situation to be structured? How are students to demonstrate new media competencies, and how will these be measured and evaluated? At the same time, a reproduction of analog epistemology and classroom hierarchy flourishes in this new era of digital education (e.g., witness many of the educational settings within Second Life). In other quarters, implicit understandings of the representation, expression, and organization of knowledge and discourse become problematic as internet-mediated realities challenge the adequacy of conventional classroom practices, in part because formal educational contexts and objectives may have limited relevance to the immediate-and mediated-social, communicative, and informational needs of students. What follows is an outline of a nascent initiative which we are terming bridging activities, named for its focus on developing learner awareness of vernacular digital language conventions and analyzing these conventions to bridge in-class activity with the wider world of mediated language use.

Our pedagogical proposal is that advanced foreign language learning can be served by combining the best of the analytic traditions of schooling with the life experiences and future needs of today's foreign language students. Specifically, we advocate the use of a teacher-mediated language awareness framework, contributions from participating students who search for and bring in texts that are relevant to their immediate or projected future communicative interests, and the use of contrastive analysis, data-driven learning (i.e., corpus-informed analyses), and qualitative discourse analysis methodologies. The ultimate goal extends beyond high-level foreign language proficiency to include intercultural and symbolic competence as part of an increasingly plurilingual, multiliterate global citizenry (e.g., Kramsch, 2006; Thorne, 2006). As proposed by the New London Group (1996), the concept of multiliteracies describes two essential arguments. The first is that schooling needs to take account of the multiple channels of communication and media now in popular use. The second is the need to acknowledge the increasing salience of multiple cultures and linguistic diversity and, concomitantly, the strategic displacement of conventional notions of 'language' by contingently and thoughtfully assembled semiotic fragments and repertoires in everyday contexts of communicative activity (see also Thorne \& Lantolf, 2007).

The bridging activities model involves incorporating and seriously analyzing studentselected texts within the advanced foreign language curriculum. This represents a move that, under ideal conditions, provides vivid, context-situated, and temporally immediate interaction with "living" language use. Bridging activities are not intended to be a replacement for standard texts or reference grammars. Rather, they are meant to provide a realia counterweight to the prescriptivist versions of grammar, style, and vocabulary in foreign language texts that typically are not based upon actual language use (for exceptions, see Carter, Hughes, \& McCarthy, 2000; Thorne, Reinhardt, \& Golombek, 2008).

Language awareness is premised on the principles of noticing and eventually understanding and predicting the variable rules, probabilities, and linguistic choices associated with 
particular modalities, contexts and communities, and interpersonal relationships (e.g., Carter, 1998), a skill that, if well developed, would serve an individual across a lifetime of changing linguistic, social, and professional activity. Translated into a pedagogical approach, the thrust behind bridging activities is to raise learner awareness of the grammatical and lexical choices that comprise a text and to have the learner critically consider how these linguistic choices combine to realize different textual, interpersonal, and ideational meanings in situational and cultural contexts (e.g., Halliday \& Matthiesen, 2004). Within this language awareness framework, learners examine extended excerpts of actual language use and are guided in their exploration of the relationships between features of the texts, the social contexts in which they function (genre), and the social realities specific language choices will tend to instantiate. McCarthy and Carter (1994) offer several principles that aim to develop awareness of language as discourse. These include the contrastive principle, which focuses on differences within comparable text types and/or language used to achieve particular social actions; the continuum principle, involving exposure to a variety of texts in the same genre but produced by different authors; and the inferencing principle which teaches strategies for cultural and literary understanding, or interpretative skills. In essence, our use of language awareness focuses on bringing explicit attention to recurrent discursive and linguistic features of texts and then discussing these aspects of linguistically structured communication openly and directly with learners with the goal of fostering metalinguistic knowledge.

With bridging activities, a core pedagogical principle is to raise the agentive possibilities for foreign language students. This is accomplished by having students themselves select and bring in "them-relevant" internet-mediated texts that they find to be exemplars of a genre and, with appropriate teacher mediation, to stylistically analyze the texts, asking "why do certain texts and textual or discourse conventions work well (with a given audience, context, and purpose) and others not?" Following this, a comparison can be made between the internet texts and genre-approximate analog text types produced for school or mainstream media distribution, asking "what are the differences between the internet-mediated and more traditional texts? How are these differences linguistically and stylistically realized? What are the interpersonal, sociocultural, informational, and ideological purposes of these texts?" In practice, both teachers and students would engage with these questions and attempt to develop bridging activities that minimally serve two functions: (a) to highlight attention to linguistic and rhetorical forms as they relate to the production of meaning and/or social actions and (b) to increase the practical relevance and contemporary currency of an institution's foreign language courses. Examples of new media literacies that we are examining and for which we are creating materials are described below.

\section{Instant Messaging and Synchronous Chat}

For regular users of synchronous text communication tools, the hallowed sentence has given way to the clause, fragment, alphanumeric convention, and acronym. Yet to communicate otherwise with full participants in chat culture, for example using complete sentences and formal punctuation, would mark such an interlocutor as unsophisticated. Additionally, chat conventions vary widely across languages and user communities, requiring frequent adaptation, often extemporaneously, to maintain meaningful and engaging communication. Contrastive questions that can guide exploration include the following:

1. How does instant messaging differ from spoken conversation? (Note: Students can be encouraged to transcribe a few minutes of interactive social talk for comparison)

2. What graphical elements are common to chat but not found in formal written prose, and vice versa? What function do these graphical elements serve? 
3. What linguistic elements of chat are shared with other forms of written language, and which, if any, are unique (e.g., contractions, utterance length of individual posts, sentence initial elements, acronyms, emoticons, etc.)?

4. Are there grammatical constructions or formulaic sequences that are recurring in chat? If so, what are they? What communicative, interactive, and/ or phatic function(s) do they serve (e.g., as discourse makers, interactional resources for holding or allocating the floor, units of talk that enhance intersubjectivity or mark epistemic stance, self- and other-correction strategies, comprehension checks, clarification of misunderstandings, etc.)?

\section{Blogs and Wikis}

Blogs and wikis are second generation web applications and represent relatively modest technological advancements over their static webpage predecessors. Of the two, blogs are more commonly used by individuals, the media, and organizations and have recently come to play a significant role in public discourse, while wiki technologies create the possibility for collaboratively authored and elaborated textual production that has resulted in extraordinary resources such as Wikipedia (http://www.wikipedia.org). Each of these technologies enables traditional forms of expository and narrative prose while also supporting the emergence of novel composition processes and contexts of reception. Contrastive questions that can guide exploration include the following:

1. How do news blog entries differ from conventional newspaper articles?

2. How are social-personal blog entries distinct from other comparable texts such as personal essays or journal writing?

3. Find a blog you enjoy reading regularly. What makes it readable and popular? What stylistic elements can you pinpoint that contribute to its success (e.g., pronoun and lexical choice, affective stance markers, presence or absence of logical connectors, or other discrete elements of style)?

\section{Remixing}

There are a range of new language and literacy practices associated with the "practice of taking cultural artifacts and combining and manipulating them into a new kind of creative blend" (Lankshear \& Knobel, 2006, p. 106). Lankshear and Knobel, in a later publication, make the following observations:

Even the concept of "text" as understood in conventional print terms becomes a hazy concept when considering the enormous array of expressive media now available to everyday folk. Diverse practices of "remixing"-where a range of original materials are copied, cut, spliced, edited, reworked, and mixed into a new creation-have become highly popular in part because of the quality of product it is possible for "ordinary people" to achieve. $(2007$, p. 8)

These comments address a core challenge in the development of advanced level foreign language proficiency and, more broadly, gaining high level proficiency in any area. Passive or receptive comprehension is not enough. Mastery requires production (e.g., Swain, 1985, 2000). So why not, in good Vygotskian fashion, encourage learners to "cheat?" (This is a veiled reference to the zone of proximal development, e.g., Vygotsky, 1978; within applied linguistics, see Lantolf \& Thorne, 2006; Thorne, 2003.) In other words, a student might be 
able to assemble an otherwise impossibly sophisticated and creative text if encouraged to appropriate, and to imitate, existing texts, literary aesthetics, and models. To take a specific example of language-based remixing, Black $(2006,2007)$ describes fanfiction as a practice by which enthusiasts of various media such as books, movies, television, comics, and video games borrow elements of these popular cultural texts, such as characters, settings, literary tropes, and plotlines, to construct their own narrative fictions. Fans often remix these various media, combining multiple genres, languages, and cultural elements; for example, Black describes English as a second language learners inserting Japanese terms and Asian cultural references into Japanese animation or anime-based fanfiction that is written in English and set within a North American story context. Remixing practices can also illustrate a plurality of registers, for instance alterations between formal narrative prose and online social registers (Black, 2005, 2007; Lankshear \& Knobel, 2006; Thorne \& Black, 2008). By encouraging learners to borrow from and build upon existing characters and story lines, and to creatively adapt and extend language and cultural contexts, the product of their labors may significantly exceed what might be possible in conventional essay or creative fiction tasks. In terms of helping learners analyze fanfiction and other remixing texts and media, questions might include the following:

1. For a remixing text, can you identity the multiple genres present?

2. What linguistic and rhetorical features standout as clearly borrowed from other genres and literary and cultural contexts?

3. Which text features have been recombined or rearticulated in a new or creative way?

4. How do specific elements of language used in the local text being analyzed (e.g., lexical choice, phrases, and quoted or reported speech) indexically tie it to other source-media or cultural contexts?

\section{Multiplayer Online Gaming}

Online multiplayer games are massively popular with some games involving millions of players worldwide (e.g., Blizzard Entertainment's World of Warcraft, http://www.blizzard.com/us). Gaming environments provide opportunities for immersion in distinctive linguistic, cultural, and task-based settings (see Gee, 2003; Squire, 2003; Steinkuehler, 2006; Thorne, 2008c). An array of specific literacy practices are associated with such games that utilize language and other in-game semiotic means to develop strong "projective" identities, defined as long-term and usually consistent identity performances that players project onto their in-game characters (Gee, 2004). Questions might include:

1. How is communication used as a resource in the immediacy of in-game problem solving and play?

2. What sorts of speech functions are common? For example, do you see instances involving the soliciting of help, providing directions, reprimanding and apologizing, sharing of information and strategy, introductions/greeting and leave-taking rituals, or other kinds of language use that might be common to other contexts?

3. What kind of talk goes on in gaming environments that does not relate directly to game play? Examples might be off-topic (nongame) banter, overtures of friendship, and complaints or accolades regarding general qualities of the game.

4. How do more experienced and less experienced online game players differ in their in-game chat? 
5. Are there lexical and/or text-convention differences between in-game chat and other common internet communication tools, such as instant messenger?

\section{PEDAGOGICAL INTEGRATION AND APPLICATION OF BRIDGING ACTIVITIES}

Incorporating bridging activities into the advanced foreign language syllabus involves the integration of learning objectives that promote the development of language awareness across these various media and modalities. Key to a pedagogical application of the model is student selection of internet/new media literacy texts, which ensures a high probability that the texts will be relevant to the kinds of communicative practices in which students either already are or want to become engaged for interpersonal, recreational, and professional purposes. The more general advanced language proficiency goals of the model include:

1. to improve understanding of both conventional and internet-mediated text genres, emphasizing the concept that specific linguistic choices are associated with desired social-communicative actions;

2. to raise awareness of genre specificity (why certain text types work well for specific purposes) and context-appropriate language use;

3. to build metalinguistic, metacommunicative, and analytic skills that enable lifelong learning in the support of participation in existing and future genres of plurilingual and transcultural language use;

4. to bridge toward relevance to students' communicative lives outside of the classroom; and

5. to increase student agency in relation to the choice, content and stylistic specifics of the texts contributing to the language learning process.

Similar to the New London Group's (1996) cycle of situated practice, overt instruction, critical framing, and transformed practice, a pedagogical application of the bridging activities model would include a 3-phase cycle of activities centered on observation and collection, guided exploration and analysis, and creation and participation. Observation activities ask students to develop awareness of their own internet use habits and to collect texts of interest. Guided exploration and analysis activities lead students to notice and critically examine the linguistic and social features of the observed and collected texts. In creation and participation activities, students join internet communities and participate in text creation, which leads to new observations and analyses.

An integrated project that incorporates this 3-phase cycle might have students build a portfolio of texts they have collected, analyzed, and created, perhaps in a blog or wiki format with weekly or monthly entries which they annotate with reflective commentary. The guided analysis activities could take the form of reviews and reports of the various websites, gaming environments, remixing texts, blogs, videos, and podcasts students have chosen and collected. Analysis could also include concordancing and keyword activities based on datadriven learning principles (Cobb, 1997; see also O'Keefe, McCarthy, \& Carter, 2007). Another analysis activity might have students compare and contrast texts within one linguistic community (e.g., two different blogs in Spanish), across linguistic communities (e.g., a threaded discussion in Chinese with one in English), or within one social community (e.g., a selection of different text types associated with a particular fan group, movie, or video game). A participation/creation activity might have students reformulate the genre of a particular text (Kern, 2001), for example, change a chat or discussion board thread to a face-to-face conversation or, more authentically, create video mashups or remixed texts and post them to YouTube, or 
a fanfiction site or join a chat or game in the target language. This participation then leads to observation and analysis of subsequent texts and practices.

\section{CONCLUSION}

The above description of new media, multiliteracies framework, and mediated language awareness pedagogy attempts to balance the resources and performance potentials of internet generation youth with the knowledge bases, analytic traditions, and conceptual-theoretical frameworks that the institution of foreign language education can provide. To be clear, the bridging activities approach is designed to enhance engagement and relevance through the incorporation of students' digital-vernacular expertise, experience, and curiosity, coupled with instructor guidance at the level of semiotic form to explore interactional features, discourselevel grammar, and genre. The ultimate goal is to foster critical awareness of the anatomy and functional organization of a wide range of communicative practices relating to both digital and analogue textual conventions.

The brief examples of new media literacies and bridging activities presented above also precipitate a number of challenges to the conventional goals and processes of advanced foreign language education, such as the rigidity of the gate-keeping mechanisms of highstakes testing that recognize only analogue genres, the disconnect between the prescriptivist epistemology of schooling and the language use that is appropriate and even necessary for full participation in other contexts (internet-mediated and otherwise), and what should or could be done to incorporate, and perhaps formally value, a plurality of ubiquitous digital communication practices that are generally considered stigmatized or, at best, vernacular linguistic varieties. In an age marked by transcultural and hybrid genres of communication and in a global arena where, in some quarters, "plurilingualism" is already fronted as the goal of foreign language education (witness the Common European Framework of Reference for Languages, http://www.coe.int/t/dg4/linguistic/CADRE_EN.asp), these issues will increase in intensity and complexity and must necessarily inform the foreign language educational frameworks of the future.

\section{REFERENCES}

Black, R. W. (2005). Access and affiliation: The literacy and composition practices of English-language learners in an online fanfiction community. Journal of Adolescent and Adult Literacy, 49(2), 118-128.

Black, R. W. (2006). Language, culture, and identity in online fanfiction. E-learning, 2(2), $170-184$.

Black, R. W. (2007). Digital design: English language learners and reader feedback in online fanfiction. In M. Knobel \& C. Lankshear (Eds.), A new literacies sampler (pp. 115-136). Bern: Peter Lang.

Black, R. W., \& Steinkuehler, C. (in press). Literacy in virtual worlds. In L. Christenbury, R. Bomer, \& P. Smagorinski (Eds.), Handbook of Adolescent Literacy Research. New York: Guilford Press.

Byrnes, H. (Ed.). (2006). Advanced language learning: The contribution of Halliday and Vygotsky. London: Continuum. 
Byrnes, H. (2007). Locating the advanced learner in theory, research, and educational practice: An introduction. In H. Byrnes, H. Weger-Guntharp, \& K. Sprang (Eds.), Educating for advanced foreign language capacities: Constructs, curriculum, instruction, assessment (pp. 1-14). Washington, DC: Georgetown University Press.

Byrnes, H., \& Hiram, M. (Eds.). (2004). Advanced foreign language learning: A challenge to college programs. Boston: Heinle.

Byrnes, H., Weger-Guntharp, H., \& Sprang, K. (Eds.). (2007). Educating for advanced foreign language capacities: Constructs, curriculum, instruction, assessment. Washington, DC: Georgetown University Press.

Carter, R. (1998). Orders of reality: CANCODE, communication, and culture. ELT Journal, 52(1), 4356.

Carter, R., Hughes, R., \& McCarthy, M. (2000). Exploring grammar in context. Cambridge: Cambridge University Press.

Carter, R., \& Simpson, P. (Eds.). (1989). Language, discourse, and literature: An introductory reader in discourse stylistics. Cambridge: Cambridge University Press.

Castells, M. (Ed.). (2004). The network society: A cross-cultural perspective. Northampton, MA: Edward Edgar.

Cobb, T. (1997). Is there any measurable learning from hands-on concordancing. System, 25(3), 301315.

Cope, B., \& Kalantzis, M. (Eds.). (2000). Multiliteracies: Literacy learning and the design of social futures. New York: Routledge.

Crystal, D. (2001). Language and the internet. Cambridge: Cambridge University Press.

Darhower, M. (2002). Instructional features of synchronous computer-mediated communication in the L2 class: A sociocultural case study. CALICO Journal, 19(2), 249-277. Retrieved April 14, 2008, from https://calico.org/p-5-Calico\%20Journal.html

Fowler, R. (1986). Linguistic criticism. Oxford: Oxford University Press.

Gee, J. P. (2003). What video games have to teach us about learning and literacy. New York: Palgrave Macmillan.

Gee, J. P. (2004). Situated language and learning: A critique of traditional schooling. London: Routledge.

Halliday, M. A. K., \& Matthiesen, C. (2004). An introduction to functional grammar. London: Arnold.

Hegelheimer, V., \& Fisher, D. (2006). Grammar, writing, and technology: A sample technology-supported approach to teaching grammar and improving writing for ESL learners. CALICO Journal, 23(2), 257-279. Retrieved April 14, 2008, from https://calico.org/p-5-Calico\%20Journal.html

Herring, S. (Ed.). (1996). Computer-mediated communication: Linguistic, social and cross-cultural perspectives. Philadelphia: John Benjamins.

Ingold, C. (2002). The reading four project: Applied technology at the higher levels of foreign language acquisition. In B. L. Leaver \& B. Shekhtman (Eds.), Developing professional-level language proficiency (pp. 141-155). Cambridge: Cambridge University Press.

Kang, S., \& Maciejewski, A. A. (2000). A student model of technical Japanese reading proficiency for an intelligent tutoring system. CALICO Journal, 18(1), 9-40. Retrieved April 14, 2008, from https:// calico.org/p-5-Calico\%20Journal.html

Kasper, G., \& Rose, K. (2002). Pragmatic development in a second language. Oxford: Blackwell.

Kern, R. (2001). Literacy and language teaching. Oxford: Oxford University Press. 
Kramsch, C. (2006). From communicative competence to symbolic competence. The Modern Language Journal, 90(2), 249-252.

Kress, G. (2003). Literacy in the new media age. New York: Routledge.

Lafford, B., Lafford, P., \& Sykes, J. (2007). Entre dicho y hecho ...: An assessment of the application of research from second language acquisition and related fields to the creation of Spanish CALL materials for lexical acquisition. CALICO Journal, 24(3), 497-529. Retrieved April 14, 2008, from https://calico.org/p-5-Calico\%20Journal.html

Lambert, R. (2001). Updating the foreign language agenda. Modern Language Journal, 85(3), $347-362$.

Lankshear, C., \& Knobel, M. (2006). New literacies: Changing knowledge and classroom learning (2nd ed.). Philadelphia: Open University Press.

Lankshear, C., \& Knobel, M. (2007). Sampling "the new" in new literacies. In M. Knobel \& C. Lankshear (Eds.), A new literacies sampler (pp. 1-24). New York: Peter Lang.

Lantolf, J. P., \& Thorne, S. L. (2006). Sociocultural theory and the genesis of second language development. Oxford: Oxford University Press.

Leaver, B. L., \& Shekhtman, B. (Eds.). (2002). Developing professional-level language proficiency. Cambridge: Cambridge University Press.

Lee, J. S. (2006). Exploring the relationship between electronic literacy and heritage language maintenance. Language Learning \& Technology, 10(2), 93-113. Retrieved April 14, 2008, from http:// Ilt.msu.edu/vol10num2/lee/default.html

McCarthy, M., \& Carter, R. (1994). Language as discourse: Perspectives for language teaching. London: Longman.

Modern Language Association. (2007). Foreign languages and higher education: New structures for a changed world. New York: Author. Retrieved April 14, 2008, from http://www.mla.org/flreport

New London Group. (1996). A pedagogy of multiliteracies. Harvard Educational Review, 66(1), 60-92.

O'Keefe, A., McCarthy, M., \& Carter, R. (2007). From corpus to classroom: Language use and language teaching. Cambridge: Cambridge University Press.

Payne, S., \& Whitney, P. J. (2002). Developing L2 oral proficiency through synchronous CMC: Output, working memory, and interlanguage development. CALICO Journal, 20(1), 7-32. Retrieved April 14, 2008, from https://calico.org/p-5-Calico\%20Journal.html

Reinhardt, J., \& Thorne, S. L. (2007). Technology for advanced foreign language proficiency: A manual for professional teacher development, Vol. 1: SCMC, blogs, \& wikis. University Park, PA: The Pennsylvania State University, Center for Advanced Language Proficiency Education and Research.

Roth, W. M. (2006). Literacies, from a dialectical perspective. Mind, Culture, and Activity, 13(4), 279282.

Savignon, S. J., \& Roithmeier, W. (2004). Computer-mediated communication: Texts and contexts. CALICO Journal, 21(2), 265-289. Retrieved April 14, 2008, from https://calico.org/p-5-Calico\%20 Journal.html

Squire, K. (2003). Video games in education. International Journal of Intelligent Simulations and Gaming, 2(1), 49-62.

Steinkuehler, C. A. (2006). Massively multiplayer online videogaming as participation in a discourse. Mind, Culture, \& Activity, 13(1), 38-52.

Strauss, S. (2005-07). Korean grammar in discourse and interaction. Unit 1-6. University Park, PA: The Pennsylvania State University, Center for Advanced Language Proficiency Education and Research. 
Strauss, S., Lee, J., \& Ahn, K. (2006). Applying conceptual grammar to advanced-level language teaching: The case of two completive constructions in Korean. The Modern Language Journal, 90(2), 185-209.

Swain, M. (1985). Communicative competence: Some roles of comprehensible input and comprehensible output in its development. In S. Gass \& C. Madden (Eds.), Input in second language acquisition (pp. 235-256). New York: Newbury House.

Swain, M. (2000). The output hypothesis and beyond: Mediating acquisition through collaborative dialogue. In J. Lantolf (Ed.), Sociocultural theory and second language acquisition (pp. 97-114). Oxford, England: Oxford University Press.

Sykes, J., Oskoz, A., \& Thorne, S. L. (2008). Web 2.0, synthetic immersive environments, and the future of language education. CALICO Journal, 25(3), 528-546. Retrieved May 1, 2008, from https:// calico.org/p-5-Calico\%20Journal.html

Thorne, S. L. (2003). Artifacts and cultures of use in intercultural communication. Language Learning \& Technology, 7(2), 38-67. Retrieved April 14, 2008, from http://lt.msu.edu/vol7num2/thorne/ default.html

Thorne, S. L. (2006). Pedagogical and praxiological lessons from internet-mediated intercultural foreign language education research. In J. Belz \& S. Thorne (Eds.), Internet-mediated intercultural foreign language education (pp. 2-30). Boston: Thomson Heinle.

Thorne, S. L. (2008a). Computer-mediated communication. In N. Hornberger \& N. Van Duesen-Scholl (Eds.), Encyclopedia of language and education (2nd ed.): Vol. 4. Second and foreign language education (pp. 325-336). New York: Springer.

Thorne, S. L. (2008b). Mediating technologies and second language learning. In D. Leu, J. Coiro, C. Lankshear, \& M. Knobel (Eds.), Handbook of research on new literacies (pp. 417-449). Mahwah, NJ: Erlbaum.

Thorne, S. L. (2008c). Transcultural communication in open internet environments and massively multiplayer online games. In S. Magnan (Ed.), Mediating discourse online (pp. 305-327). Amsterdam: John Benjamins.

Thorne, S. L. (in press). [Review of the book Educating for advanced foreign language capacities: Constructs, curriculum, instruction, assessment]. Studies in Second Language Acquisition.

Thorne, S. L., \& Black. R. W. (2007). New media literacies, online gaming, and language education. (CALPER Working Paper Series, No. 8). University Park, PA: The Pennsylvania State University, Center for Advanced Language Proficiency Education and Research.

Thorne, S. L., \& Black, R. (2008). Language and literacy development in computer-mediated contexts and communities. Annual Review of Applied Linguistics, 27, 133-160.

Thorne, S. L., \& Lantolf, J. (2007). The linguistics of communicative activity. In S. Makoni \& A. Pennycook (Eds.), Disinventing and reconstituting languages (pp. 170-195). Clevedon, UK: Multilingual Matters.

Thorne, S. L., \& Payne, J. S. (2005). Evolutionary trajectories, internet-mediated expression, and language education. CALICO Journal, 22(3), 371-397. Retrieved April 14, 2008, from https:// calico.org/p-5-Calico\%20Journal.html

Thorne, S. L., Reinhardt, J., \& Golombek, P. (2008). Mediation as objectification in the development of professional discourse: A corpus-informed curricular innovation. In J. Lantolf \& M. Poehner (Eds.), Sociocultural theory and the teaching of second languages (pp. 256-284). London: Equinox.

Vygotsky, L. S. (1978). Mind in society: The development of higher psychological processes (M. Cole, V. John-Steiner, S. Scribner, \& E. Souberman, Eds.). Cambridge, MA.: Harvard University Press.

Widdowson, H. G. (1992). Practical stylistics. Oxford: Oxford University Press. 


\section{APPENDIX}

Center for Advanced Language Proficiency Education and Research (CALPER)

Technologies for Advanced Foreign Language Proficiency Project

\section{Intra-Class Uses of Technology}

To assist instructors with classroom and formally class linked uses of technology, the CALPER Technology project has developed two resources, the Computer-Meditated Activity Library and a teacher professional development manual. The Computer-Meditated Activity Library contains explicit instructions for the FL classroom implementation of synchronous chat, blog, and wiki technologies. Activities represent diverse topic areas and activity types that emphasize spontaneous language production as well as extended narrative and collaborative compositions. Included are instructor and student directions for each activity, ACTFL standards relevant to the activity, a glossary of technology terms, and a bibliography containing additional resources. Find the Computer-Mediated Activity Library at http://calper.la.psu.edu/ $\mathrm{cmc}$ /index.php. Note: We wish to acknowledge that the Computer-Mediated Activity Library was initially conceptualized by Scott Payne and has been subsequently developed by Steven Thorne and Jonathon Reinhardt (current co-directors of CALPER's Technology Project), with contributions from Luke Eilderts, Lisa Hundley, Duff Johnston, Ty Hollett, Sungwoo Kim, Jane Klaus, Emily Rine, Jake VanderKolk, and Dana Webber. Arlo Bensinger serves as the Technical Advisor.

As a companion to the Activity Library, The CALPER professional development document, Technology for Advanced Foreign Language Proficiency: A Manual for Professional Teacher Development, Vol. 1: SCMC, Blogs, \& Wikis (Reinhardt \& Thorne, 2007), provides in-depth technical explanations of each technology, descriptions of their broader (non-educational) uses, pedagogical activities for each tool, and discussion of possible student learning outcomes associated with different communication tools and activities. Find this document at http://calper.la.psu.edu/technology.php. Future manuals for other technologies are in preparation.

Together, the Activity Library and accompanying manual provide detailed guidance for the use of technology as an integrated component of advanced foreign language curricula. Additionally, CALPER working papers provide comprehensive overviews of early and contemporary uses of synchronous chat, blog, and wiki related foreign language acquisition research and pedagogy (e.g., Thorne, 2006).

\section{AUTHORS' BIODATA}

Steven L. Thorne is Assistant Professor in the Department of Applied Linguistics and Associate Director of the Center for Language Acquisition at the Pennsylvania State University. He also serves as the Advisor for Mediated Learning at the Center for Advanced Language Proficiency Education and Research (http://calper.la.psu.edu). His interests include new media literacies, CALL, intercultural communication, and projects that engage cultural-historical activity theory, contextual traditions of language analysis, and usage-based approaches to language development. His book length works include a co-edited volume, Internet-mediated Intercultural Foreign Language Education (Thomson/Heinle, 2006) and the co-authored monograph Sociocultural Theory and the Genesis of Second Language Development (Oxford University Press, 2006). 
Jonathon Reinhardt is Assistant Professor in the Department of English at the University of Arizona and Co-Director of the Technologies Project at the Center for Advanced Language Proficiency Education and Research at the Pennsylvania State University. His research focuses on L2 pedagogy and teacher development, technology and language learning, and learner corpus analysis. His work has appeared in International Journal of Applied Linguistics and most recently in Mediated Discourse Online (Benjamins, 2008).

\section{AUTHORS' ADDRESSES}

Steven L. Thorne

Department of Applied Linguistics

The Pennsylvania State University

305 Sparks Building

University Park, PA 16802-5203

Phone: 8148657036

Fax: 8148657944

Email: sthorne@psu.edu

Jonathon Reinhardt

Department of English

University of Arizona

P.O. Box 210067

Tucson, AZ 85721

Email: jonreinhardt@yahoo.com 